\title{
A Qualitative test of Primary and Secondary Metabolites of Bintaro Plant as a Rat (Rattus argentiventer) Pest Repellent
}

\author{
Rini susanti, Risnawati, Wiznie Fadhillah
}

Agrotechnology Study Program, Muhammadiyah University of North Sumatra, Medan, Indonesia J1. Kapten Mukhtar Basri No. 3, Glugur Darat II, East Medan, Medan, North Sumatra 20238, Indonesia.

Correspondence authors: rinisusanti@umsu.ac.id

\begin{abstract}
Bintaro is a mangrove plant that grows on the coast and is often used as a shade tree in megacities. The toxic content of the Bintaro plant is found in all parts of the plant. The toxic content of cardiac glycoside compounds contained in the Bintaro plant can be used as a rat repellent. Rat pests are important pests in crops, especially in rice plants which are difficult to control in mechanically and chemically, thus rice production always decreases. Therefore, it is necessary to search for effective, efficient, and environmentalfriendly control technology, namely by using fruit extracts. The plant-based rodenticides made from Bintaro fruit extracts are effective for overcoming rat pests. The purpose of the study was to determine the qualitative levels of primary and secondary metabolites from Bintaro plants which act as antifeedants for rat pests (Ratus argiventer). The method used in this research was qualitative testing using phenol method to test the content of primary and secondary metabolites in the leaves and stems of Bintaro plants. From the results of the research conducted, it was found that the qualitative levels of primary metabolites from Bintaro leaves and stems contained protein content. Fat and carbohydrate content of secondary metabolites found in the stems and leaves of the Bintaro plants were Alkaloids, Saponins, Flavonoids and Polyphenols in Bintaro leaves and on its stems contained Flavonoids, Saponins, Tannins and alkaloids.
\end{abstract}

Keywords — Bintaro, rat pests, primary and secondary metabolites content.

\section{INTRODUCTION}

Bintaro is a mangrove plant that grows a lot on the coast and is often used as a shade tree in megacities. This Bintaro plant is known for its high toxic content, where the poison from the Bintaro plant has been used for various uses since the early 15 th century. The toxic content in the Bintaro plant is found in all parts of the plant, especially its fruit, which has the highest toxic content.

In Asian society, especially Indonesia, Bintaro fruit is widely used as a rat pest repellent. So far, the handling of rat pests has been carried out using commercially-available rodenticides. Considering of many dangers posed by rodents which have anticoagulant-based ingredients, alternative ways of controlling rat pests were developed. One of the alternative ways to control rat pests is to utilize the content of ISSN: $2456-1878$

https://dx.doi.org/10.22161/ijeab.55.16 one of the characteristics of Bintaro fruit. The toxic content of cardiac glycoside compounds contained in Bintaro fruit seeds can be used as a rat repellent.

In general, there are two kinds of metabolism, namely primary metabolism and secondary metabolism. Primary metabolism produces primary metabolites, while secondary metabolism produces secondary metabolites. Primary metabolism is present in all organisms with almost the same processes and pathways, whereas secondary metabolism has specific and unique pathways and products for each organism. Primary metabolism is directly involved in growth, whereas secondary metabolism is not involved (Anurag et al., 2015).

Primary metabolites modify and synthesize carbohydrates, fats, proteins and nucleic acids, while 
secondary metabolites produce secondary metabolites of relatively small size, generally with a molecular weight of less than 3000 Da. Primary metabolites play a role in the processes of photosynthesis and respiration, while secondary metabolites play a more important defensive role in plants (Anurag et al., 2015).

In plants, secondary metabolite compounds have several functions, including as attractants (attracting other organisms), defense against pathogens, protection and adaptation to environmental stress, protection against ultraviolet rays, as growth regulators and to compete with other plants (allelopathy). Secondary metabolites are also suspected as waste or plant detoxification products, however, most of the function of secondary metabolites is still unknown (Dewick, 2009; Kabera et al., 2014). Research on secondary metabolites is still one of the largest areas of research field to determine the function and pharmacological properties of each secondary metabolite (Kabera et al., 2014).

This research was conducted to determine the qualitative levels of primary and secondary metabolites from Bintaro which can function as a biorodenticide.

\section{RESEARCH METHODOLOGY}

The research was conducted in the laboratory of the Faculty of Agriculture, Muhammadiyah University of North Sumatra, Medan.

The materials used in this study were Bintaro plants (leaves and stems), alcohol, methanol, aquades, and others that support the research.

The tools used in this study were beaker glass, test tube, spatula, Erlenmeyer flask, stopwatch, calculator, writing instruments and others that support this research.

\section{Qualitative test of primary metabolites}

\section{Sample Preparation}

The samples used in this study were the leaves and stems of Bintaro. A total of 100 grams were cut into small pieces. Then dried using an oven at $60^{\circ} \mathrm{C}$ for 6 hours.

\section{Preparation of standard glucose solution}

A total of $0.1 \mathrm{~g}$ of glucose powder was weighed and then put into a $100 \mathrm{~mL}$ flask. A total of $10 \mathrm{~mL}$ of glucose stock solution was taken using a pipette then put into a $100 \mathrm{~mL}$ measuring flask and diluted to the limit mark. The glucose standard solution was made with the concentrations of 0,10 , $20,30,40,50 \mathrm{ppm}$ by piping out the glucose standard ISSN: 2456-1878

https://dx.doi.org/10.22161/ijeab.55.16 solution as much as $0,5,10,15,20 \mathrm{~mL}$ then put into a $50 \mathrm{~mL}$ measuring flask and diluted to the marking area. The next step was measuring the absorbance with a spectrophotometer at a wavelength of $490 \mathrm{~nm}$, then making its linear equation as standard curve (Bintang, 2010).

\section{Determination of carbohydrates (Phenol Method)}

10 grams of Bintaro plant samples (stems and leaves) were weighed, then furnaced for 5 hours. 1 gram of sample ash was taken and dissolved in $10 \mathrm{~mL}$ concentrated $\mathrm{HNO}$, then filtered in a $10 \mathrm{~mL}$ measuring flask. Then, the filtrate diluted with distilled water to mark the boundaries. Furthermore, 1 $\mathrm{mL}$ was taken and then added $1 \mathrm{~mL}$ of phenol $1 \%$ and $6 \mathrm{~mL}$ of sulfuric acid and $2 \mathrm{~mL}$ of distilled water. The mixture was allowed to stand at room temperature and then its absorption was measured at a wavelength of $490 \mathrm{~nm}$. The treatment was repeated twice (duplo)

\section{Determination of Protein (Kjeldhal Method)}

A total of 1 gram sample was weighed, then put into a kjeldahl flask, added 1 tablet kjeldhal. Then $10 \mathrm{~mL}$ of concentrated sulfuric acid solution was added and all the ingredients were digested (heated) in the Kjeldahl flask until it boiled and dissolved and the liquid turned clear. $75 \mathrm{~mL}$ of distilled water was diluted and cooled to room temperature. $10 \mathrm{~mL}$ of the filtrate was taken to determine the total nitrogen content and determined using a spectrodirect at a wavelength of $410 \mathrm{~nm}$. The treatment was repeated twice (duplo).

\section{Qualitative test of secondary metabolites}

The leaves and stems of fresh Bintaro are cleaned and then cut into small pieces. Furthermore, the cut-offs were dried for 7 days (1 week). After drying, then mashed the sample using a blender until smooth. After that, the leaves, stems and smooth Bintaro fruit were ready to be extracted. The manufacture of Bintaro plant extract began by weighing 10 grams of Bintaro powder (leaves and stems). After that, the sample was put into an Erlenmeyer flask and added with 100 $\mathrm{mL}$ of aquades. Then closed the Erlenmeyer flask using aluminum foil and soaked for $3 \times 24$ hours (48 hours) and shook it using an orbital shaker. After 72 hours the extract was filtered using a filter and the filtrate obtained was used in testing for secondary metabolites. The steps were the same for the extraction treatment with ethanol solvents.

Test of Secondary Metabolite Compounds from Bintaro Plant Extracts Extracted with Water and Ethanol Solvents Alkaloid Test

The test was carried out by taking $2 \mathrm{~mL}$ of each sample (leaves and stems) of Bintaro which had been extracted with 
water and ethanol solvents into 2 different test tubes. After that each extract was added with 5 drops of Dragendroff reagent. If each solution forms an orange precipitate, it is positive that it contains alkaloids. Furthermore, for Alkaoid testing using mayer reagent was carried out by taking $2 \mathrm{~mL}$ of each sample (leaves, stems and fruit) Bintaro which had been extracted with water and ethanol solvents into 2 different test tubes. After that each extract was added with 3 drops of concentrated hydrochloric acid and 5 drops of Mayer's reagent. If each solution forms a white precipitate, then the sample is positive that it contains alkaloids (Mustikasari \& Ariyani, 2010).

\section{Flavonoid Test}

The test was carried out by taking $2 \mathrm{~mL}$ of each sample (leaves and stems) of Bintaro which had been extracted with water and ethanol solvents, then heated for about 5 minutes. After being heated, each added 0.1 gram of $\mathrm{Mg}$ metal and 5 drops of concentrated $\mathrm{HCl}$. If each solution forms a yellow orange to red color, then it is positive that it contains flavonoids (Mustikasari \& Ariyani, 2010).

\section{Saponin Test}

The test was carried out by taking $2 \mathrm{~mL}$ of each sample (leaves and stems) of Bintaro which had been extracted with water and ethanol solvents. The sample was put into a test tube, added $10 \mathrm{ml}$ of hot water, cooled and then shook vigorously for 10 minutes). The reaction is positive if foam is formed which is steady for not less than 10 minutes, $1 \mathrm{~cm}$ to $10 \mathrm{~cm}$ high. With the addition of 1 drop of $2 \mathrm{~N}$ hydrochloric acid, the foam does not disappear (Arif et al, 2015).

\section{Polyphenol Test}

The test was carried out by taking $2 \mathrm{~mL}$ of each sample (leaves and stems) of Bintaro which had been extracted with water and ethanol solvents. Then it was reacted with $1 \%$ $\mathrm{FeCl} 3$ solution, if it forms green, red, purple, dark blue, blackish blue or greenish black, it indicates the presence of phenolic compounds (Kurratul et al., 2014).

\section{Tannin Test}

The test was carried out by taking $2 \mathrm{~mL}$ of each sample (leaves and stems) of Bintaro which had been extracted with water and ethanol solvents, then heated for about 5 minutes. After heating, each of them added a few drops of $1 \% \mathrm{FeCl} 3$. If each solution forms a greenish brown or blue-black color, it is positive for tannins (Marlinda et al, 2012).

\section{RESULTS AND DISCUSSION}

\section{Primary Metabolites}

From the research that has been done, it was found that the primary metabolite contents in Bintaro plants can be seen in table 1 below

Table 1. Primary Metabolites Content

\begin{tabular}{|l|l|l|l|l|}
\hline No & Sample & Fats & Protein & Carbohydrates \\
\hline 1 & $\begin{array}{l}\text { Bintaro } \\
\text { Leaves }\end{array}$ & $\begin{array}{l}14.60 \\
\%\end{array}$ & $0.024 \%$ & $3.21 \%$ \\
\hline 2 & Bintaro & $\begin{array}{l}12.80 \\
\%\end{array}$ & $0.013 \%$ & $3.54 \%$ \\
& Stems & & \\
\hline
\end{tabular}

From table 1, it can be seen that the highest content of primary metabolites in fat content is in Bintaro leaves, namely $14.60 \%$, while the highest is carbohydrate content, which is $3.54 \%$. Primary Metabolites are usually used to synthesize glucose through the process of photosynthesis to produce energy for plants.

\section{Secondary Metabolites}

From the results of the research that has been done, it was found that the content of secondary metabolites in Bintaro plants can be seen in table 2 below:

\begin{tabular}{|l|l|l|l|}
\hline No & $\begin{array}{l}\text { Secondary } \\
\text { Metabolites }\end{array}$ & Leaves & Stems \\
\hline 1 & Flavanoid & + & + \\
\hline 2 & Saponin & + & + \\
\hline 3 & Tanin & - & + \\
\hline 4 & Polifenol & + & - \\
\hline 5 & Alkaloid & + & + \\
\hline
\end{tabular}

From table 2 above, it can be seen that the leaves contain secondary compounds, namely flavonoids, saponins, polyphenols, and alkaloids, while the stems contain flavonoids, saponins, tannins, and alkaloids.

The stems contain tannin compounds which are insect repellents. Insects that consume a suitable food source will grow and develop well. On the other hand, insects that consume food sources that have inadequate nutrients will experience inhibition in their growth and development. Likewise, insects whose food contains certain chemical compounds will be inhibited growth and development. Such compounds are found in plants (Dadang and Priyono, 2008) 
Alkaloids contain in the stems and leaves of the Bintaro plant are toxic, as food inhibitors and insecticides for insects. According to Cahyadi (2009) alkaloid and flavonoid compounds can act as stomach poisons. Therefore, if the alkaloid and flavonoid compounds enter the insect's body, their digestive organs will be disturbed.

Flavonoids found in the stems and leaves of Bintaro are chemical compounds that have insecticidal properties. Flavonoids attack several nerve organs in several vital organs of insects, resulting on nerves weakening, such as breathing and death. Flavonoids work as respiratory inhibitors. Inhibitors are substances that inhibit or decrease the rate of chemical reactions, flavonoids also affect the energy mechanism in the mitochondria by inhibiting the electron transport system (Roqib and Kristanti, 2015).

Saponins found in the stems and leaves of the Bintaro plant can affect the absorption of minerals and vitamins. Southon et al. (1988) stated that saponins reduce iron absorption in tested mice. The decrease in absorption is more due to the influence of the disturbance of $\mathrm{Fe}$ transport through mucosal cells compared to the bonds formed between Fe and saponins.

\section{REFERENCES}

[1] Apriantono, A., Dedi, F., Puspitasari, N., Sedarmawati \& Slamet, B. (1988). Analisis pangan. Bandung: ITB.

[2] Arif, R., Sri,W dan Ike Y, W. 2015. Isolasi dan Identifikasi Senyawa Saponin Ekstrak Metanol Daun Binahong (Anredera cordifolia (ten.) steenis). Jurnal Online Mahasiswa (JOM) Bidang Farmasi. Vol.1 No. 1.

[3] Cahyadi, R. (2009). Uji Toksisitas Akut Ekstrak Etanol Buah Pare (Momordica charantia L.) Terhadap Larva Artemia salina Leach Dengan Metode Brine Shrimp Lethality Test (BST). Skripsi. Semarang: Universitas Diponegoro.

[4] Handoko, T. Suhandiaya, G. Mulyana,H. 2012. Hidrolisis Serat Selulosa Dalam Buah Bintaro Sebagai Sumber Bahan Baku Bioetanol. Jurnal Teknik Kimia Indonesia, Volume 11 No $1 \quad$ (2012), halaman 26-33. Universitas Parahiyangan. Bandung

[5] Harborne, J. B. (1987). Metode fitokimia penentuan cara modern menganalisis tumbuhan. Bandung: ITB.

[6] Hariyatimi. (2004). Kemampuan vitamin e sebagai antioksidan terhadap radikal bebas pada lanjut usia. Jurnal MIPA, 14, 52-60.

[7] Hermiati, Rusli, Manalu, N. Y., \& Sinaga, M. S. (2013). Ekstrak daun sirih hijau dan merah sebagai antioksidan pada minyak kelapa. Departemen Teknik Kimia, Fakultas Teknik, Universitas Sumatera Utara, 2(1).
[8] Hertiani, T., Pramono, S., \& A.M, S. (2000). Uji daya antioksidan senyawa flavonoid daun (Plantago major L.). Majalah Farmasi Indonesia, 11(4), 234.

[9] Juniaty Towaha dan Gusti Indriati. 2011. Potensi Tanaman Bintaro (Cerbera Manghas) Sebagai Alternatif Sumber Bahan Bakar Nabati. Warta Penelitian Dan Pengembangan Tanaman Industri. Volume 17 Nomor 1, April 2011. ISSN 0853-8204

[10] Kurratul A, Betty L dan Balqis. 2014. Skrining Fitokimia dan Penentuan Aktivitas Antioksidan Serta Kandungan Total Fenol Ekstrak Buah Labu Siam (Sechium edule (jacq.) Sw.). Diploma Thesis, Universitas Negeri Malang.

[11] Prayuda, Y.E. 2014. Efikasi Ekstrak Biji Bintaro (Cerbera manghas) Sebagai Larvasida pada Larva Aedes aegypti LInstar III/ IV. Program Studi PendidikanDokter Fakultas Kedokteran dan Ilmu Kesehatan UIN Syarif Hidayatullah Jakarta.

[12] Rahayu, Pakki.T, Sukmawati. 2014. Preferensi dan Kemampuan Makan Tikus Rumah (Rattus diardii) pada Beberapa Varietas Beras (Oryza sativa) di Penyimpanan. Jurnal Agroteknos 4(1):66-70Sa'adah, L. (2010). Isolasi dan identifikasi senyawa tanin dari daun belimbing wuluh (Averrhoa bilimbi 1.). Universitas Islam Negeri (UIN) Maulana Malik Ibrahim, Malang.

[13] Roqib, M dan Kristanti, I. P. 2015. Pengaruh Ekstrak Daun Beluntas (Pluchea indica) terhadap Mortalitas dan Perkembangan Larva Spodoptera litura F. Jurnal Sains Dan Seni Its Vol. 4, No.2

[14] Septyaningsih, D. (2010). Isolasi dan identifikasi komponen utama ekstrak biji buah merah ( Pandanus conoideus lamk). Universitas Sebelas Maret, Surakarta

[15] Southon, S., A.J.A. Wright, K.R. Price, S.J. Fairweather-Tait, \& G.R. Fenwick. 1988. The effect of three types of saponin on iron and zinc absorption from a single meal in the rat. British Journal of Nutrition. 59: 389-3 